Cultural and socioeconomic determinants of invention: A multicountry, multiperiod analysis

Habib, Mohsin;Coombs, Joseph E

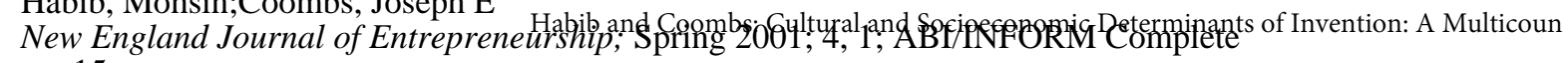
pg. 15

\title{
Cultural and Socioeconomic Determinants of Invention: A Multicountry, Multiperiod Analysis
}

\author{
Mohsin Habib \\ Joseph E. Coombs
}

This article examines the influence of culture and socioeconomic variables on national invention. For the overall sample, individualism and power distance affects invention. Human capital, infrastructure, and gross domestic product (GDP) per capita also affect invention. These relationships are consistent across two different time periods. When the sample is divided into developed and developing economies, cultural dimensions, in general, lose their significance. Also, the socioeconomic variables are only significant for developing countries. These findings have implications for policy-makers involved in developing the appropriate context for innovative entrepreneurial activities.

$\mathbf{G}$ lobalization has created a fiercely competitive marketplace where both companies and their countries compete. At the country level, being competitive in the international arena means better employment, wages and eventually, better standards of living for citizens (Cohen et al. 1984). Thus, how to improve national competitiveness is a topic of concern for both businesses and governments. Competitiveness largely depends on how dynamic and creative a country is. Schumpeter originally proposed that innovation is critical for national development (Schumpeter 1934). He added that the innovation process works by means of "creative destruction" engineered by entrepreneurs. The three related components of entrepreneurship-innovativeness, proactiveness, and constructive risk-taking - when put together result in invention (Miles and Arnold 1991; and Morris, Avila, and Allen 1993). More recently, Porter reemphasized the original proposal arguing that innovation (the marketing of invention) is the key to the development of internationally competitive industries (Porter 1990). Greater innovative ability makes it possible to constantly upgrade current technology for tomorrow's competition and allows countries to outperform others in productivity, quality, and response time.

This article focuses on invention as a critical element of national competitiveness and examines its determinants. First, based on international management literature, the link between culture and national invention is analyzed. Second, acknowledging the fact that economics matter, socioeconomic factors that affect invention are considered. Third, the effects on developed and developing countries are analyzed separately. Finally, two time periods, 1980 and 1990, are used to test the consistency of the effects.

This research differs from previous studies on several dimensions. First and most importantly, effects of culture and socioeconomic variables are analyzed separately for developed and developing countries. This is crucial because factors promoting invention may have different effects based on the countries' level of development. It also helps to address the question of whether, for example, culture matters once countries have moved beyond the developing stage. These issues have yet to be addressed and constitute the main focus of this article. Second, analyzing both cultural and socioeconomic factors in this study provide a basis for comparison between the two effects. A relative comparison has been largely ignored in prior studies. Finally, the time period considered here is more recent than other studies keeping in mind the constraints imposed by cultural dimension measures.

While this study is conducted at the country level, the authors acknowledge that invention takes place fundamentally at the level of individual entrepreneurs and their organizations. Identifying country-level determinants may help develop policies that would improve the context for innovation and facilitate the entrepreneurial orientation of individuals and organizations.

\section{Cultural Dimensions and Invention}

Most of the research on national culture has built upon the seminal work of Hofstede (1980). He defined culture as the "collective programming of the mind which distinguishes the members of one group from another." This collective programming develops gradually over time and continues to survive for a long period. Hofstede identified four major dimensions of culture:

- power distance,

- individualism,

- uncertainty avoidance, and

- masculinity.

\section{Power Distance}

Power distance represents primarily the organizational hierarchy that exists in a society. A high power distance country is one where there is an unequal distribution of 
power due to multiple levels of hierarchy (Hotstede 1980). Bureaucracy inhibits invention in high power distance countries because it reduces communication between superiors and subordinates (Shane 1992). Open communication, on the other hand, increases innovation because it helps to generate new ideas (Thompson 1967). Researchers have suggested decentralization as a means of generating greater levels of innovation because it helps to disseminate information and presents new technology to decision-makers (Hage and Aiken 1970).

Decentralization also allows greater feedback from front-line staff. Another aspect of hierarchical societies is that they rely more on formal control systems than trust, resulting in reduced creativity and inventiveness. Trust in subordinates encourages innovation while rigid control can make employees passive and reduce creative thinking (Quinn 1979; Sathe 1988; and Shane 1992).

\section{Individualism}

The need for freedom, nonconformity, and an outward orientation are characteristics of individualistic societies that can be linked to innovation (Hofstede 1980; and Shane 1993). Freedom in actions and decision-making is important for creative thinking which ultimately leads to innovation (Kanter 1982; and Sathe 1988). People's willingness to violate norms and their high levels of achievement in individualistic societies are ingredients for challenging the status quo to come up with new invention (Verma 1985). Outward orientation or contact with outside individuals and groups promotes innovation by presenting new ideas (Utterback 1974). Individualistic societies also recognize and reward individual efforts which motivates innovators (Quinn 1979). Individualism, if properly promoted within an organization, can foster entrepreneurial innovative activities.

Shane tested the effects of individualism and power distance on national rates of invention using patents as the dependent variable (Shane 1992). He found individualism and low power distance countries to be more inventive than others across different time periods. He concludes that some countries have comparative advantages with respect to invention based on their cultural attributes. He further tested the effects of culture on innovation (using trademark data) and again found low power distance and individualism to be beneficial to innovation (Shane 1993). $\mathrm{He}$ also found that the effects of individualism and power distance weakened over time.

Hypothesis 1a: National rates of invention will be positively associated with individualism.

Hypothesis 1b: National rates of invention will be negatively associated with power distance.

\section{Uncertainty Avoidance}

Uncertainty avoidance represents the level of risk that a society is comfortable with in an uncertain decision-making context (Hofstede 1980). Innovation, by its very nature, is risky and uncertain. Societies that have a tolerance for risk and ambiguity, or measure high on uncertainty acceptance (opposite of uncertainty avoidance), are expected to innovate more (Kanter 1982). Managers in high uncertainty acceptance societies develop a better perception of dealing with uncertainty as they initiate changes (Shane 1993). High uncertainty acceptance also implies the willingness to try out new things (Jones and Davis 2000). Shane found a significant positive relationship between rates of innovation and uncertainty acceptance (Shane 1993).

Hypothesis 1c: National rates of invention will be negatively associated with uncertainty avoidance.

\section{Masculinity}

Masculine societies take an aggressive approach when it comes to achievement, recognition, and competitiveness (Hofstede 1980; and Jones and Davis 2000). Research has shown that prestige, accomplishment, and financial reward motivate creative managers (Quinn 1979). Thus, this article makes the point that greater emphasis on achievement, recognition, and reward in masculine societies will result in innovation.

Hypothesis 1d: National rates of invention will be positively associated with masculinity.

\section{Socioeconomic Factors and Invention}

Researchers have argued that advanced economic factors are mainly responsible for a nation's competitive advantage (Porter 1990; and Dunning 1993). Basic factors like natural resources were particularly beneficial when transportation cost was a large portion of total cost. With advancement in large-scale transportation technology, access and mobility of natural resources have increased tremendously so that it has ceased to generate long-term competitive advantage for nations. Today, according to Porter, it is technological knowledge and infrastructure, sophisticated human capital, and the organizational ability to innovate that represent advanced economic factors for a country. Dunning also argues that value-generating assets are mostly created assets like human capital and communications infrastructure instead of natural assets like land and untrained labor (Dunning 1993). He concludes that a nation's competitive advantage depends on the ability of its institutions to organize created assets and to increase the stock of these assets at lower real cost. 
Effective application of these assets should lead to greater levels of innovation that meet local demand and help countries compete internationally. Four socioeconomic factors are examined here as determinants of national invention:

- infrastructure (energy and telecommunications)

- human capital,

- GDP per capita, and

- the level of international trade.

Infrastructure and human capital represent advanced factors. GDP per capita and trade emphasize countries' income and competitiveness (Porter 1990).

\section{Infrastructure}

Policy advocates agree that a key to higher productivity and economic performance is investment in infrastructure (Munnell 1990). A good infrastructure can generate, communicate, and disseminate the goods, services, and information that are essential for invention. Two components of infrastructure considered important for innovation are electrical power facilities (as energy source) and telecommunications. The wide use of energy in almost all sectors of the economy affects national output (Klein 1988). A stable and efficient source of energy assists in conducting both normal business and different experiments of commercial value. Also, most inventions require some form of energy. Unstable and inadequate energy sources in developing countries have led to productivity loss and missed opportunities for improvement in operations. Alternate energy sources and the related advancement in technology, however, have made energy a less significant factor in production than was the case three decades ago. Telecommunications has gained prominence because of its critical role in managing operations, both locally and internationally. Without an effective telecommunications system, coordination and control of productive sectors are difficult (Mascarenhas and Sambharya 1995). The absence of an adequate telecommunications system can make firms less responsive to changing conditions leading to a lack of invention. A good telecommunications system allows countries to efficiently operate in an informationbased global economy. The ability to connect with the rest of the world helps individuals think, reason, and develop new inventions.

Hypothesis 2a: National rates of invention will be positively associated with infrastructure.

\section{Human Capital}

Scholars have suggested that a nation's productivity lay in its skilled work force (Thurow 1992). With revolutionary changes in technology that cut across all sectors of the economy, a knowledgeable, technically skilled work force is a fundamental requirement. Educated employees are better and faster in picking up new skills required for complex operations. They are also more likely to have novel ideas for improving existing technology. Education is also closely associated with a positive outlook toward innovation (Kimberly and Evanisko 1981). It has been suggested that the greater the education level of managers, the more likely they are to accept ambiguity and embrace innovative activities (Hambrick and Mason 1984).

Hypothesis 2b: National rates of invention will be positively associated with human capital.

\section{GDP}

GDP per capita is considered a factor in national invention as it represents the income and productivity of a country. Greater income demands invention and invention, in turn, generates more income (Vernon 1966). Thus, a higher GDP per capita means more "spare" resources that can be used for innovation instead of subsistence. High GDP per capita countries possess greater ability to create and market products because they better understand market' demand, and have more efficient infrastructure and distribution system (Shane 1993). Financial and institutional resources important for innovation are also associated with high income nations. In trying to explain economic growth of nations, proponents of the New Growth Theory have identified technical advance as a kay driving force. They argue that technological advance is endogenous-involving investments in human capital and R\&D by profit-seeking firms (Nelson 1997). Utilizing tecbnology for innovation and growth is an opportunity mainly available to countries with high GDP per capita.

Hypothesis 2c: National rates of invention will be positively associated with GDP per capita.

\section{International Trade}

Exposure to international trade can be fruitful for national invention. Grossman and Helpman (1991) argue:

1. International exchange opens channels of communication that facilitate the transmission of technical information.

2. International competition encourages entrepreneurs in each country to pursue new and distinctive ideas and technology.

3. International integration enlarges the size of the market in which the innovative firm operates.

4. International trade induces a reallocation of resources. 
In this process countries can gain from trade. Particularly, countries with a larger high technology sector can experience greater long-term gains.

Hypothesis 2d: National rates of invention will be positively associated with trade.

\section{Culture or Economics-Which One Will Prevail?}

There is an ongoing debate among scholars regarding the effects of globalization and culture on national development. Increasing movement of goods, services, people, and ideas across national borders is facilitating the globalization of markets (McGrath et al. 1992). Moreover, markets are integrated due to growth in technology and communications. Globalization and integration of markets are expected to make the countries' business environments more similar (Craig, Douglas, and Grein 1992). In the process, countries will benefit from global efficiency and new developments from all over the world. The concern, however, is that similarity in environments may require a gradual modification (and even destruction) of nations' distinct cultures. If national culture actually succumbs to environmental forces, then Hofstede's cultural dimension values for each country will change and will have less of an impact on innovation and development (McGrath et al. 1992).

Others have argued that the increased interaction between people has increased awareness of differences between civilizations that can bring out old animosities (Huntington 2000). Economic development and subsequent social change is also weakening the position of the nation states. Under these circumstances, nations may decide to hold on to their culture and modernize without the globalization effects (Barkema and Vermeulen 1997). The underlying assumption is that culture is stable and can thwart any imposed economic forces. If this scenario holds, culture will continue to be an important determinant of national innovation and development (Jones and Davis 2000).

Heuer, Cummings, and Hutabarat (1999) tested this hypothesis using Hofstede's individualism and power distance dimensions for Indonesia and the United States. With strong foreign influences in Indonesia, the researchers expected Indonesia's cultural measures to gradually move toward those of the United States. The results confirmed their hypothesis showing a narrowing of the differences in the cultural dimensions between the countries. Heuer et al.'s results, however, differ from another study which found no convergence in cultural distance for the Netherlands among a sample of developed and developing countries (Barkema and Vermeulen 1997).
Even Hofstede, who strongly argued for a stable national culture, agrees that a convergence of cultures may occur on the individualism dimension because of its strong association with wealth (Hofstede 1980).

While it is difficult to predict the future, it is reasonable to suggest that national culture will continue to face tremendous pressure from global economic forces. Thus, over time there is a real possibility that countries will not only modernize economically but also form a more common (mixed) culture.

Hypothesis 3: Cultural effects on national rates of invention will weaken over time.

\section{Hypothesis 4: Economic effects on national rates of invention will persist over time.}

\section{Developed v. Developing Countries}

Developing countries represent a combination of Porter's factor- and investment-driven stages (Porter 1990). In addition to basic factors of production, developing countries rely heavily on infrastructure and human skills for growth. A developed infrastructure guarantees smooth functioning of various economic sectors. Investment in human capital ensures that complex foreign technology can be applied, modified and improved upon (Porter 1990). International trade helps in this respect by providing exposure to new products and technology. Finally, existing income (GDP per capita) ensures that the focus on innovation continues.

Developed countries have achieved general improvement in human capital and infrastructure and they all have high levels of income. There is very little variance among developed countries along these dimensions. To compete against each other, they focus on differentiation that requires specialized (human) skill and (technological) infrastructure, and investments in partnerships and strategic alliances (Porter 1990). Basic improvement in human skills no longer provides an edge over other countries. Similarly, modern infrastructure, like telecommunications, is important but on its own will not offer any special competitive advantage. Lastly, greater national income (GDP per capita) will act as a catalyst for more invention, but among developed countries, the mere presence of it will not provide any advantage. It is for these reasons that our socioeconomic variables are expected to have less of an impact on developed countries than developing countries.

Cultural effects are expected to also be less for developed countries than developing countries. Developed countries have moved further in the globalization process. In an integrated global market, culture is expected to have less of an impact (McGrath et al. 1992). The conflict between preservation of culture and economic globaliza- 
tion is more prominent in developing countries. Culture, in its different forms, still plays a major role in shaping individual work attitudes, organizational orientation, and even national policies of developing countries (Huntington 2000). As a result, culture is expected to have a bigger impact on invention in developing countries.

Hypothesis 5: The socioeconomic and cultural effects on national rates of invention will be greater for developing countries than developed countries.

\section{Methodology}

This study focuses on invention by examining data on country-level patent activity for the years 1980 and 1990 . These two years are chosen because Hofstede's cultural dimensions were measured in the late 1960s and early 1970 s. Although culture is relatively stable, the authors consider a 20-year time gap (from 1970 to 1990) to be a maximum and therefore pursue no analysis after 1990. This is reasonable because researchers, including Hofstede, have hinted that individualism and power distance dimensions are potentially more malleable than stable. The samples for 1980 and 1990 were 48 and 46 countries, respectively. The small sample size is a result of the limitations imposed by cultural data. Gaps in countries' patent data also affected sample size.

Patents are a good measure of inventiveness because patented inventions must be novel, useful, and exhibit an inventive step (Evenson 1984). The use of country-level patent measures has been criticized, however, due to country-specific biases in the propensity to patent and innovate (Pavitt 1985; and Kotabe 1993) and the inability of patents to capture all facets of technical invention (Freeman and Young 1965). While these problems must be considered, country-level patenting does reflect ongoing inventive activity as well as inventors' perceptions of the benefits to patenting in their inventions in their countries (Pavitt 1985). Further, country-level patents are still good indicators of inventiveness because they do not rely on product commercialization (Shepherd 1979; and Scherer 1980). Two dependent variables are included in this study. The first variable, patents per capita, measures country-level patent activity per capita. The second variable, wealth-adjusted patents per capita, was developed by Shane (1992). This variable holds wealth constant while capturing the effect of culture on invention because greater wealth presupposes higher technology and a higher propensity to innovate (Vernon 1966). The variable is calculated in a three-step process. First, the ratio of patents per capita to gross national product (GNP) per capita is calculated for all countries to derive an average value of the number of patents associated with each dollar of GNP.
This value is multiplied by each country's GNP per capita. The resulting value represents the expected number of patents per dollar of GNP. Finally, the actual number of patents per capita is divided by the expected number of patents per dollar of GNP to create the number of wealthadjusted patents per capita. Data for patents are collected from the annual volumes of the United Nations' Statistical Yearbook.

Country culture is measured using Hofstede's cultural values - uncertainty avoidance, power distance, individualism, and masculinity (see Exhibit 1). These variables are the result of a survey of 88,000 employees in more than 40 subsidiaries of a major U.S. corporation. The survey data was used to create ordinal scales for each country on the four cultural dimensions. Research has shown these measures to have both reliability and validity (Kogut and Singh 1988). Socioeconomic variables include human capital, infrastructure, international trade, and GDP per capita. Human capital is measured in terms of male literacy rate in a country's population. Infrastructure includes telecommunication and energy. A factor analysis revealed that the number of telephones per 100 citizens and the installed electrical capacity per 1,000 inhabitants loaded on the same factor for the 1980 and 1990 data. For both electrical capacity and telephones, each data point is transformed into a z-score. The two z-scores for each country are then combined to create the new infrastructure variable. International trade is measured as export and import combined as a percentage of GDP. Data for the variables are gathered from the UN Handbook of International Trade and Development Statistics (GDP per capita and electrical capacity), World Bank World development indicators (male literacy rate), International Monetary Fund International Financial Statistics Yearbook (international trade), and the UN Statistical Yearbook (telephones per 100 citizens).

\section{Results}

Exhibit 2 provides the correlation matrix for all of the variables. An examination of the correlation matrix suggests that a moderate amount of collinearity exists among the independent variables. While moderate levels of collinearity do not violate the assumptions of ordinary least-squares (OLS) regression, the study's correlations are sufficiently high that multicollinearity diagnostics were generated and examined. The researchers examined the variable inflation factor (VIF) for evidence of problematic levels of multicollinearity. Studenmund (1992) suggested a VIF cutoff level of 10 while Hair et al. (1992) recommended a cutoff of 5.3. The VIF statistic for GDP per capita in Exhibits 4 $(\mathrm{VIF}=4.661)$ and $5(\mathrm{VIF}=4.327)$ approached 5.3. To avoid problems associated with multicollinearity, the authors dropped GDP per capita from the remaining regression 


\section{Exhibit 1 Hofstede's Cultural Measures}

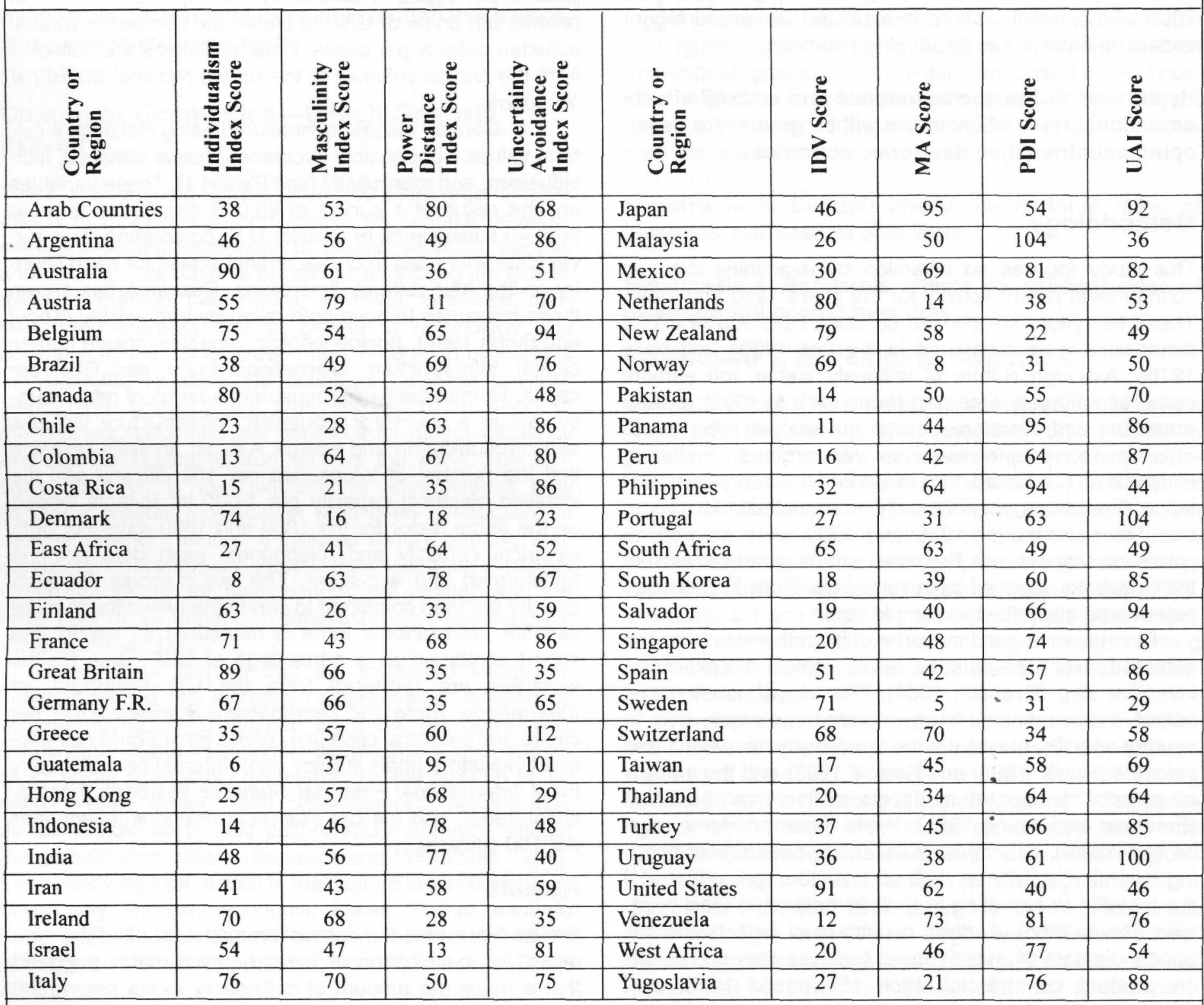

Arab Countries: Egypt, Iraq, Kuwait, Lebanon, Libya, Saudi Arabia, United Arab Emirates, East Africa: Ethiopia, Kenya, Tanzania, Zambia, West Africa: Ghana, Nigeria, Sierra Leone

Source: G. F. Hofstede. 1991. Cultures and Organizations: Software of the Mind. New York: McGraw-Hill.

analyses. Spearman-rank correlation and ordinary leastsquare regression are used in this study for data analysis. Spearman-rank correlation is appropriate for examining ordinal variables and has been used to analyze cultural dimensions and country-level data (Shane 1992). Regression analysis is used here to test the explanatory power of cultural variables after controlling for economic variables. Given the small sample size, regression analysis is restricted by sample size and is not performed for developed and developing country subsamples.

Exhibit 3 reports the correlation results for the full set of countries in 1980 and 1990. Supporting Hypothesis 1a, individualism is positively and significantly correlated with both patents per capita and wealth-adjusted patents per 


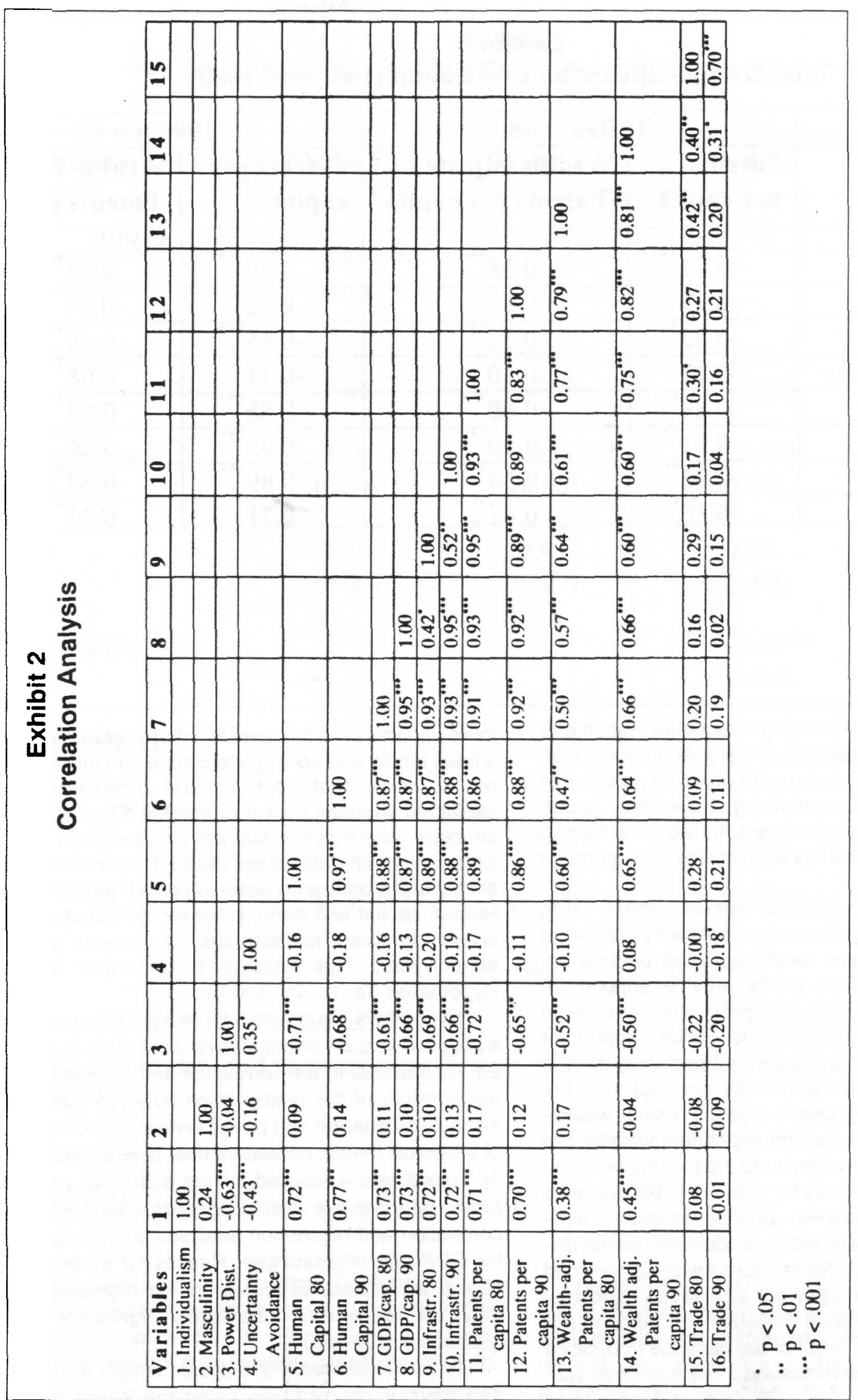




\section{Exhibit 3}

Total Sample Spearman Correlation (1980 and 1990)

\begin{tabular}{l|c|c|c|c|}
\hline & \multicolumn{2}{|c|}{$1980 \mathrm{n}=\mathbf{4 8}$} & \multicolumn{2}{c}{$1990 \mathrm{n}=46$} \\
\hline $\begin{array}{l}\text { Independent } \\
\text { Variables }\end{array}$ & $\begin{array}{l}\text { Patents } \\
\text { per capita }\end{array}$ & $\begin{array}{l}\text { Wealth-adjusted } \\
\text { Patents per capita }\end{array}$ & $\begin{array}{l}\text { Patents per } \\
\text { capita }\end{array}$ & $\begin{array}{l}\text { Wealth-adjusted } \\
\text { Patents per } \\
\text { capita }\end{array}$ \\
\hline Individualism & $0.71^{* * *}$ & $0.38^{* * *}$ & $0.70^{* * *}$ & $0.45^{* * *}$ \\
\hline Masculinity & 0.17 & 0.17 & 0.12 & -0.04 \\
\hline Power distance & $-0.72^{* * *}$ & $-0.52^{* * *}$ & $-0.65^{* * *}$ & $-0.50^{* * *}$ \\
\hline Uncertainty avoidance & -0.17 & -0.10 & -0.11 & 0.08 \\
\hline Human Capital & $0.89^{* * *}$ & $0.60^{* * *}$ & $0.88^{* * *}$ & $0.64^{* * *}$ \\
\hline GDP/capita & $0.91^{* * *}$ & $0.50^{* * *}$ & $0.92^{* * *}$ & $0.66^{* * *}$ \\
\hline Infrastructure & $0.95^{* * *}$ & $0.64^{* * *}$ & $0.89^{* * *}$ & $0.60^{* * *}$ \\
\hline Trade & $0.30^{*}$ & $0.42^{* *}$ & 0.21 & $0.31^{*}$ \\
\hline
\end{tabular}

$$
\begin{array}{ll}
* & p<.10 \\
* & p<.05 \\
* * & p<.01 \\
& p<.001
\end{array}
$$

capita in 1980 and 1990. Providing support for Hypothesis $1 b$, power distance is negatively and significantly correlated with patents per capita and wealth adjusted patents per capita for both years. The remaining dimensions, uncertainty avoidance and masculinity, are not significantly correlated with the patent variables and provide no support for Hypotheses 1c and 1d.

The socioeconomic variables, human capital, GDP, and infrastructure are significant and positively correlated with patents per capita and wealth-adjusted patents per capita for both years. The results provide support for Hypotheses $2 a, b$, and $c$. Trade is significantly correlated in three out of four cases and provide partial support for Hypothesis 2d. Exhibits 4 and 5 present regression analyses for 1980 and 1990 using patents per capita as the dependent variable. Regression results using wealthadjusted patents per capita as the dependent variable are not shown because they are similar to the patents per capita results. Each set of analyses for 1980 and 1990 includes the total sample of countries. Due to potential multicollinearity problems of GDP with individualism, power distance, human capital, and infrastructure it was not included in subsequent models in each set of analysis. The four economic variables explained between 70 percent (for 1990) and 73 percent (for 1980) of the variance (Exhibits 4 and 5). Excluding GDP, the remaining three economic variables explained between 40 and 63 percent. Using these three variables (human capital, infrastructure, and trade) as a base model and adding one culture variable at a time, the results show that each cultural dimension increased explained variance by 4 to 9 percent. Overall, GDP, infrastructure, and individualism are positively and significantly associated with patents per capita. Power distance is negatively and significantly associated with patents per capita. Human capital and trade, however, do not show any consistent significant relationships with patents per capita in either year. The findings lend further support for Hypotheses 1a, 1b, 2a, and 2c.

Hypothesis 3 suggested there would be a weakening of cultural effects on invention over time. This is not supported. As depicted in the correlation and regression analyses the strength of the relationships between cultural dimensions (individualism and power distance) and national rates of invention remain consistent over time (Exhibits 3, 4, and 5). Hypothesis 4 focused on the economic variables and predicted a positive effect that holds across time. Both the correlation and regression analyses provide good support for GDP and infrastructure. Results for trade and human capital are mixed. Especially in the regression analysis, they fail to remain consistently significant over time (Exhibits 3, 4, and 5).

To test Hypothesis 5, the data is split into developed and developing countries using the World Bank defini- 


\section{Exhibit 4}

Results of Regression Analysis for Patents Per Capita for $1980^{\text {a }}$

\begin{tabular}{|c|c|c|c|c|}
\hline $\begin{array}{l}\text { Independent } \\
\text { Variables }\end{array}$ & Model 1 & Model 2 & Model 3 & Model 4 \\
\hline GDP/capita & $\begin{array}{l}0.62 * * * \\
(0.00)\end{array}$ & & & \\
\hline Human Capital & $\begin{array}{c}0.10 \\
(0.00)\end{array}$ & $\begin{array}{c}0.29^{*} \\
(0.00)\end{array}$ & $\begin{array}{c}0.21^{+} \\
(0.00)\end{array}$ & $\begin{array}{c}0.18 \\
(0.00)\end{array}$ \\
\hline Infrastructure & $\begin{array}{c}0.19 \\
(0.00)\end{array}$ & $\begin{array}{l}0.61^{* * *} \\
(0.00)\end{array}$ & $\begin{array}{l}0.40^{* *} \\
(0.00)\end{array}$ & $\begin{array}{l}0.42^{* * * *} \\
(0.00)\end{array}$ \\
\hline Trade & $\begin{array}{l}-0.03 \\
(0.00)\end{array}$ & $\begin{array}{l}-0.05 \\
(0.00)\end{array}$ & $\begin{array}{l}0.00 \\
(0.00)\end{array}$ & $\begin{array}{l}0.00 \\
(0.00)\end{array}$ \\
\hline Individualism & & & $\begin{array}{l}0.35^{* *} \\
(0.00)\end{array}$ & \\
\hline Power Distance & & & & $\begin{array}{l}-0.37^{* *} \\
(0.00)\end{array}$ \\
\hline $\mathrm{R}^{2}$ & 0.73 & 0.63 & 0.69 & 0.70 \\
\hline $\mathbf{F}$ & $26.95 * * *$ & $23.65^{* * *}$ & $22.05 * * *$ & - $23.71^{* * *}$ \\
\hline d.f. & 41 & 42 & 41 & 41 \\
\hline \multicolumn{5}{|c|}{$\begin{array}{l}\text { "Values are standardized regression coefficients with standard errors in parentheses. } \\
+p<.10 \\
{ }^{*} p<.05 \\
{ }^{* *} p<.01 \\
{ }_{* * *} p<.001\end{array}$} \\
\hline
\end{tabular}

tion. For 1980 , those countries with a GNP per capita above $\$ 4,880$ are classified as developed. For 1990 , the GNP per capita cutoff is $\$ 7,620$. Exhibits 6 and 7 present correlation results for developed and developing countries.
As shown in Exhibit 6, for the developed countries, power distance is negatively and significantly correlated with patents per capita in 1980 , and wealth-adjusted patents per capita in both 1980 and 1990. Among the socioeconomic variables, GDP is only correlated with 
Exhibit 5

Results of Regression Analysis for Patents Per Capita for $1990^{\circ}$

\begin{tabular}{|c|c|c|c|c|}
\hline $\begin{array}{l}\text { Independent } \\
\text { Variables }\end{array}$ & Model 1 & Model 2 & Model 3 & Model 4 \\
\hline GDP/capita & $\begin{array}{l}1.01 * * * \\
(0.00)\end{array}$ & & & \\
\hline Human Capital & $\begin{array}{l}-0.10 \\
(0.00)\end{array}$ & $\begin{array}{c}0.21 \\
(0.00)\end{array}$ & $\begin{array}{l}0.12 \\
(0.00)\end{array}$ & $\begin{array}{c}0.10 \\
(0.00)\end{array}$ \\
\hline Infrastructure & $\begin{array}{l}-0.17 \\
(0.00)\end{array}$ & $\begin{array}{l}0.47^{* *} \\
(0.00)\end{array}$ & $\begin{array}{c}0.33^{\dagger} \\
(0.00)\end{array}$ & $\begin{array}{c}0.28^{+} \\
(0.00)\end{array}$ \\
\hline Trade & $\begin{array}{c}0.21^{*} \\
(0.00)\end{array}$ & $\begin{array}{c}0.17 \\
(0.00)\end{array}$ & $\begin{array}{c}0.19 \\
(0.00)\end{array}$ & $\begin{array}{r}0.20^{+} \\
(0.00)\end{array}$ \\
\hline Individualism & & & $\begin{array}{c}0.29^{+} \\
(0.00)\end{array}$ & \\
\hline Power Distance & & & & $\begin{array}{l}-0.40^{* *} \\
(0.00)\end{array}$ \\
\hline $\mathrm{R}^{2}$ & 0.70 & 0.40 & 0.44 & 0.49 \\
\hline $\mathbf{F}$ & $22.59^{* * *}$ & $8.69 * * *$ & $7.44^{* * *}$ & $9.23^{* * *}$ \\
\hline d.f. & 39 & 40 & 39 & 39 \\
\hline \multicolumn{5}{|c|}{$\begin{array}{l}\text { a Values are standardized regression coefficients with standard errors in parentheses. } \\
+\quad \mathrm{p}<.10 \\
{ }^{*} \quad \mathrm{p}<.05 \\
{ }^{* *} \mathrm{p}<.01 \\
* * * \mathrm{p}<.001\end{array}$} \\
\hline
\end{tabular}

patents per capita in 1990, infrastructure is only correlated with patents per capita in 1980, and trade is only correlated with patents and wealth-adjusted patents per capita in 1990. All other correlations are nonsignificant.

Results for developing countries reveal that power dis- tance is significantly correlated with only wealth-adjusted patents per capita in 1980 while uncertainty avoidance is positively correlated with patents per capita and wealthadjusted patents per capita in 1990 (Exhibit 7). Of the socioeconomic variables, GDP, infrastructure, and human 


\section{Exhibit 6}

Developed Countries Spearman Correlation (1980 and 1990)

\begin{tabular}{|c|c|c|c|c|}
\hline & \multicolumn{2}{|c|}{$1980 n=18$} & \multicolumn{2}{|c|}{$1990 n=21$} \\
\hline $\begin{array}{l}\text { Independent } \\
\text { Variables }\end{array}$ & $\begin{array}{l}\text { Patents } \\
\text { per } \\
\text { capita }\end{array}$ & $\begin{array}{l}\text { Wealth-adjusted } \\
\text { Patents per } \\
\text { capita }\end{array}$ & $\begin{array}{l}\text { Patents } \\
\text { per capita }\end{array}$ & $\begin{array}{l}\text { Wealth- } \\
\text { adjusted } \\
\text { Patents per } \\
\text { capita }\end{array}$ \\
\hline Individualism & -0.21 & -0.10 & -0.09 & -0.15 \\
\hline Masculinity & 0.05 & 0.26 & -0.20 & -0.16 \\
\hline Power distance & $-0.54^{*}$ & $-0.41^{\dagger}$ & -0.35 & $-0.50^{*}$ \\
\hline $\begin{array}{l}\text { Uncertainty } \\
\text { avoidance }\end{array}$ & -0.32 & -0.21 & 0.14 & 0.06 \\
\hline Human Capital & 0.30 & 0.18 & 0.36 & 0.24 \\
\hline GDP/capita & 0.29 & -0.23 & $0.68^{* * *}$ & 0.31 \\
\hline Infrastructure & $0.55^{* *}$ & 0.35 & 0.34 & 0.08 \\
\hline Trade & 0.09 & -0.03 & $0.55^{* * *}$ & $0.72^{* * *}$ \\
\hline 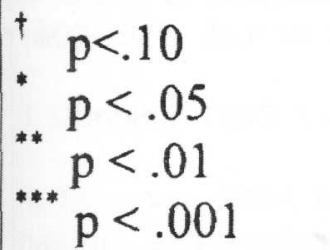 & & & & - \\
\hline
\end{tabular}

capital are all significantly correlated with patents per capita and wealth-adjusted patents per capita for both years. Trade is only correlated with patents and wealth adjusted patents per capita in 1980.

Exhibits 6 and 7 provide partial support for Hypothesis 5. When the sample is divided into developed and developing countries, it becomes clear that the effects of the cultural variables are similar within each group. Power distance is the only significant cultural dimension and even then it is not consistent. Thus, culture appears unable to explain national invention for developed and developing countries. However, economic effects are very different between the two groups. As hypothesized, for developing countries, the impact of economic factors is much more direct and important for invention.

\section{Discussion and Conclusions}

This study has examined the role of culture and socioeconomic variables on national invention. Determining the sources of invention can help researchers and policy-makers understand the basis for competitive advantage of nations. This analysis was performed on a larger sample of countries than previously done (Shane 1992). It also looked into the relationships separately for developed and developing countries. Finally, the analysis examined the effects across two different time periods, 1980 and 1990. Since the time period of the study ends in 1990 there may be questions regarding the applicability of the results in today's context. While this may be a problem, and thus a limitation of this study, the authors believe that the fundamental question of the effects of culture and socioeconomics (which are fairly stable) on innovation have been highlighted. In that respect, the implications are relevant for the current time as it involves setting the right context, policies, and processes for invention. Future research should reevaluate the dynamics of the specific variables and draw new arguments and measures to capture them.

Analysis of the total sample presents significant results of culture and economic variables in both time periods. The roles of individualism and low power distance in promoting national invention are consistent with previous studies (Shane 1992; Shane 1993; and Kanter 1982). These two 


\section{Exhibit 7}

Developing Countries Spearman Correlation (1980 and 1990)

\begin{tabular}{|c|c|c|c|c|}
\hline & \multicolumn{2}{|c|}{$1980 n=30$} & \multicolumn{2}{|c|}{$1990 n=25$} \\
\hline $\begin{array}{l}\text { Independent } \\
\text { Variables }\end{array}$ & $\begin{array}{l}\text { Patents } \\
\text { per } \\
\text { capita }\end{array}$ & $\begin{array}{l}\text { Wealth adjusted } \\
\text { Patents per } \\
\text { capita }\end{array}$ & $\begin{array}{l}\text { Patents } \\
\text { per capita }\end{array}$ & $\begin{array}{l}\text { Wealth } \\
\text { adjusted } \\
\text { patents per } \\
\text { capita }\end{array}$ \\
\hline Individualism & 0.21 & 0.28 & 0.06 & 0.11 \\
\hline Masculinity & 0.15 & 0.10 & -0.02 & -0.11 \\
\hline Power distance & -0.29 & $-0.32^{\dagger}$ & -0.05 & -0.08 \\
\hline $\begin{array}{l}\text { Uncertainty } \\
\text { avoidance }\end{array}$ & 0.20 & 0.13 & $0.42^{*}$ & $0.42^{*}$ \\
\hline Human Capital & $0.72^{* * 4}$ & $0.61^{* * *}$ & $0.63^{* * *}$ & $0.39^{\dagger}$ \\
\hline GDP/capita & $0.86^{* * *}$ & $0.61^{* * *}$ & $0.79^{* * *}$ & $0.67^{* * *}$ \\
\hline Infrastructure & $0.92^{* * *}$ & $0.80^{* * *}$ & $0.83^{* * *}$ & $0.62^{* * *}$ \\
\hline Trade & $0.48^{* n}$ & $0.58^{* * *}$ & 0.15 & 0.06 \\
\hline $\begin{array}{l}+p<.10 \\
p<.05 \\
*_{* *} p<.01 \\
p<.001\end{array}$ & & & & - \\
\hline
\end{tabular}

cultural dimensions differentiate the successful innovators from the not so successful ones. Similarly, the overall sample shows a positive effect of the economic variables (mainly GDP per capita, infrastructure and human capital) on national invention. Based on these results, one can conclude that countries having such cultural and economic characteristics will enjoy an advantage over others. At the country level, policies must ensure a favorable context for entrepreneurial development that can spur innovation. Policy-makers must take a proactive approach to encourage creativity by reducing unnecessary bureaucracy (low power distance) and providing greater freedom to the private sector (promoting individualism and achievement) to engage in risky but potentially important projects. In addition, a long-term commitment to investment in knowledge development (human capital) and infrastructure is a must. All these initiatives should lead to greater entrepreneurial orientation for the individuals and organizations alike. Companies can do their part by redefining their priorities to include creativity, providing incentives for risk-taking, designing a flexible workplace, and placing more emphasis on intangible asset development.

This study provides further insight into the knowiedge of country competitiveness by separately looking at developed and developing countries. For the developed country sample, only power distance showed significant effects on national invention. Bureaucracy, it seems, is a major hindrance to invention even in developed countries. The cultural results are worse for the developing country sample. Overall, culture explained very little when the sample is separated into developed and developing countries. These results, when taken in conjunction with the overall sample results, suggests that culture explains primarily the difference in invention between the developed and developing countries. That is, developing countries must overcome some of the cultural effects to become as innovative as developed countries. However, taken separately, there are no cultural effects within the developing country sample only. Similarly, developed countries have no significant competitive advantage compared to each other on the basis of cultural dimensions (except for some difference in power distance). This is an important point overlooked in 
previous literature. Culture is important when moving beyond the developing stage but is less important when countries are already developed and involved in the global marketplace.

Similar to culture, the socioeconomic variables have almost no effect on developed countries. These countries have reached a stage in the development process where all have good infrastructure, human capital, and GDP. Raising the average level of these factors no longer provides a competitive advantage. The results presented here support Porter's (1990) argument that it is the ability to specialize that drives innovation. For developing countries, the scenario is very different. Basic economic factors such as human capital and infrastructure are not evenly dispersed among the developing nations. Major differences in GDP per capita also exist. Invention is more geared toward basic industrialization which is not as specialized as inventions in the developed countries. Thus, developing countries with relatively good infrastructure and human capital, and with the ability to invest, can be more inventive.

Researchers interested in the analysis of national invention must take into account the development stage of countries for further insights. For developed countries, identifying industry-specific economic factors responsible for inventiveness is a fruitful agenda. For developing countries, exploring the effects of cultural dimensions in association with other contextual factors (location, existing resources and industrial base, international network) can generate a greater understanding of culture's impact on innovation. Such a contingency perspective is useful because it can identify unique options for (developing) countries to become more innovative.

\section{References}

H. Barkema and F. Vermeulen. 1997. What differences in the cultural backgrounds of partners are detrimental for international joint ventures? Journal of International Business Studies 28, no. 4, pp. 845-64.

S. Cohen, D. Teece, L. Tyson, and J. Zysman. 1984. Global competition, the new reality. Working Paper of the President's Commission on Industrial Competitiveness. California: University of California, Berkeley.

C. Craig, S. Douglas, and A. Grein. 1992. Patterns of convergence and divergence among industrialized nations: 1960-1988. Journal of International Business Studies 23, no. 4, pp. 773-787.

J. Dunning 1993. Internationalizing Porter's diamond. Management International Review 2, pp. 7-15.

R. Evenson. 1984. International invention: Implications for technology market analysis, in R. Griliches, ed., R\&D, patents, and productivity. Chicago: University of Chicago 1984.

C. Freeman and A. Young. 1965. The research and development effort in Western Europe, North America and the Soviet Union. Organization for Economic Corporation and Development, Paris.

G. M. Grossman and E. Helpman. 1991. Innovation and growth in the global economy. Cambridge, MA: The MIT Press.

J. Hage and M. Aiken. 1970. Social change in complex organizations. New York: Random House.

J. F. Hair, Jr., R. E. Anderson, R. L. Tatham, and C. Black. 1992. Multivariate data analysis. New York: Macmillan.

D. Hambrick and P. Mason. 1984. Upper echelons: The organization as a reflection of its top managers." Academy of Management Review 9, no. 2, pp.193-206.

M. Heuer, J. Cummings, and W. Hutabarat. 1999. Cultural stability or change among managers in Indonesia. Journal of International Business Studies 30, no. 3, pp. 599-610.

G. Hofstede. 1980 Culture's consequences: International differences in work related values. Beverly Hills, CA: Sage Publications.

S. Huntington. 2000. The clash of civilizations? in Frank J. Lechner and John Boli, ed., The Globalization Reader, Blackwell Publishers.

G. Jones and H. Davis. 2000. National culture and innovation: Implications for locating global R\&D operations. 
Management International Review 40, pp.11-39.

R. Kanter. 1982. The change masters. New York: Simon and Schuster.

J. Kimberly and M. Evanisko. 1981.Organizational innovation: The influence of individual, organizational and contextual factors on hospital adoption of technological and administrative innovations. Academy of Management Journal 24, pp. 689-713.

L. Klein. 1988. Components of competitiveness. Science 241, pp. 308-313.

B. Kogut and $\mathrm{H}$. Singh. 1988. The effect of national culture on the choice of entry mode. Journal of International Business Studies 19, pp. 411-430.

M: Kotabe. 1993.A comparative study of U.S. and Japanese patent systems. Journal of International Business Studies 23, pp. 147-168.

B. Mascarenhas and R. Sambharya. 1995. Sources of international competitiveness: An empirical analysis. Working Paper. New Jersey: Rutgers University.

R. McGrath, I. MacMillan, E. Yang, and W. Tsai. 1992. Does culture endure or is it malleable? Issues for entrepreneurial economic development. Journal of Business Venturing 7, pp. 441-58.

M. Miles and D. Arnold. 1991. The relationship between marketing orientation and entrepreneurial orientation. Entrepreneurship Theory and Practice 15, no. 4, pp. 49-65.

M. Morris, R. Avila, and J. Allen. 1993. Individualism and the modern corporation: Implications for innovation and entrepreneurship. Journal of Management 19, no. 3, pp. 595-612.

A. Munnell. 1990. Why has productivity growth declined? Productivity and Public Investment. New England Economic Review January-February, pp. 3-21.

R. Nelson. 1997. How new is new growth theory?" Challenge 40, no. 5, pp. 29-40.

K. Pavitt. 1985. Patent statistics as indicators of innovative activities: Possibilities and problems. Sciertometrics 7 , pp. 77-99.

M. Porter. 1990. The competitive advantage of nations. New York: The Free Press.

J. Quinn. 1979. Technological innovation, entrepreneurship and strategy. Sloan Management Review 20, pp. 19-30.

V. Sathe. 1988. Fostering entrepreneurship in the large diversified firm. Organizational Dynamics 16, pp. $20-32$.

F. Scherer. 1980. Industrial market structure and economic performance, 2nd ed. Chicago: Rand McNally.

J. Schumpeter. 1934. The theory of economic development. Cambridge, MA: Harvard University Press.

S. Shane. 1992. Why do some societies invent more than others?" Journal of Business Venturing 7, pp. 29-46.

S. Shane. 1993. Cultural influences on national rates of innovation. Journal of Business Venturing 8, pp. 59-73.

W. G. Shepherd. 1979. The economics of industrial organization. Englewood Cliffs, NJ: Prentice Hall.

A. H. Studenmund. 1992. Using econometrics: A practical guide. New York: Harper Collins.

J. Thompson. 1967. Organizations in action. New York: McGraw Hill.

28 NEW EngLand JOURNAL OF ENTREPRENEURSHIP 
L. Thurow. 1992. Head to head: The coming economic battle among Japan, Europe, and America. New York: William Morrow and Company, Inc.

J. Utterback. 1974. Innovation in industry and the diffusion of technology. Science 183, pp. 620-626.

J. Verma. 1985. The ingroup and its relevance to individual behavior: A study of collectivism and individualism. Psychologica 28, pp. 173-81.

R. Vernon. 1966. International investment and international trade in the product cycle. Quarterly Journal of Economics 80, pp. 190-197.
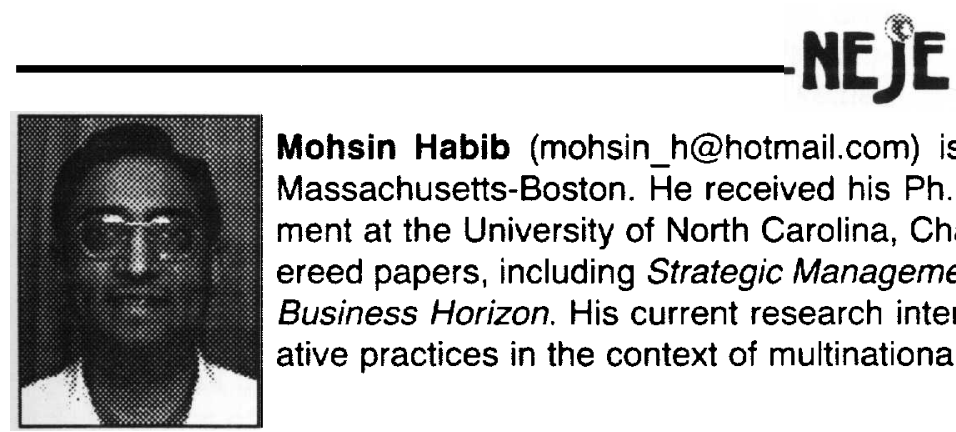

Mohsin Habib (mohsin_h@hotmail.com) is assistant professor of management at the University of Massachusetts-Boston. $\bar{H}$ e received his Ph.D. in management with an emphasis on strategic management at the University of North Carolina, Chapel Hill. Dr. Habib has published or presented multiple refereed papers, including Strategic Management Journal, Thunderbird International Business Review, and Business Horizon. His current research interests include foreign direct investment, ethics, and comparative practices in the context of multinationals.

Joseph E. Coombs (coombsje@jmu.edu) is an assistant professor of management at James Madison University. He received his Ph.D. in international business from Temple University. His research interests include investigations of how high technology firms access and use external resources to overcome the liabilities of newness and adolescence. His research has appeared in Journal of Business Venturing. Entrepreneurship Theory and Practice, Journal of High Technology Management Research, and the New England Journal of Entrepreneurship. He is the author of International Strategy and Market Performance in New Biotechnology Firms (Garland Publishing, 1999). 